Article

\title{
Numerical Analysis of Heat Transfer Performances of Ionic Liquid and Ionanofluids with Temperature-Dependent Thermophysical Properties
}

\author{
Amra Hasečcić ${ }^{1, *}$, Jaber Hmoud Almutairi ${ }^{2}$, Siniša Bikić ${ }^{3}$ and Ejub Džaferović ${ }^{1}$ (i) \\ 1 Faculty of Mechanical Engineering, University of Sarajevo, 71000 Sarajevo, Bosnia and Herzegovina; \\ dzaferovic@mef.unsa.ba \\ 2 The Public Authority for Applied Education and Training, College of Technological Studies, \\ Shuwaikh 70654, Kuwait; jh.almutairi@paaet.edu.kw \\ 3 Faculty of Technical Sciences, University of Novi Sad, 21000 Novi Sad, Serbia; bika@uns.ac.rs \\ * Correspondence: hasecic@mef.unsa.ba; Tel.: +387-33-729-825
}

check for updates

Citation: Hasečić, A.; Almutairi, J.H.; Bikić, S.; Džaferović, E. Numerical

Analysis of Heat Transfer

Performances of Ionic Liquid

and Ionanofluids with

Temperature-Dependent

Thermophysical Properties. Energies

2021, 14, 8420. https://doi.org/

$10.3390 /$ en 14248420

Academic Editor: Kamel Hooman

Received: 5 October 2021

Accepted: 17 November 2021

Published: 14 December 2021

Publisher's Note: MDPI stays neutral with regard to jurisdictional claims in published maps and institutional affiliations.

Copyright: (c) 2021 by the authors. Licensee MDPI, Basel, Switzerland. This article is an open access article distributed under the terms and conditions of the Creative Commons Attribution (CC BY) license (https:// creativecommons.org/licenses/by/ $4.0 /)$.
Abstract: The heat transfer performances of ionic liquids $\left.\left[\mathrm{C}_{4} \mathrm{mpyrr}_{[}\right] \mathrm{NTf}_{2}\right]$ and ionanofluids with $\mathrm{Al}_{2} \mathrm{O}_{3}$ nanoparticles under a laminar flow regime, and with constant heat flux on the tube wall is numerically modeled and analyzed for three values of initial/inlet temperature and for two Reynolds numbers. Heat transfer characteristics were considered by analyzing the temperature distribution along the upper wall, as well as by analyzing the Nusselt number and heat transfer coefficient. The results obtained numerically were validated using Shah's equation for ionic liquid. Thermophysical properties were temperature-dependent, and obtained by curve-fitting the experimental values of the thermophysical properties. Furthermore, the same set of results was calculated for the ionic liquid and ionanofluids with constant thermophysical properties. It is concluded that the assumption that thermophysical properties are constant has a significant influence on the heat transfer performance parameters of both ionic liquid and ionanofluids, and therefore such assumptions should not be made in research.

Keywords: ionanofluids; computational fluid dynamics; heat transfer; Nusselt number; temperaturedependent properties

\section{Introduction}

Nanofluids are a mixture of base fluid and small nanoparticles up to $100 \mathrm{~nm}$ size. It is proven that nanofluids have better thermal properties than the base fluids [1], therefore, in the last two decades, a substantial amount of research has been conducted related to the nanofluids and their application to the solar systems and other heat exchange devices. A major part of those research studies was focused on the thermophysical properties and heat transfer of nanofluids where the base fluid was water and ethylene-glycol, with nanoparticles with different oxides $\left(\mathrm{Al}_{2} \mathrm{O}_{3}, \mathrm{TiO}_{2}, \mathrm{CuO}\right.$, etc). Ribeiro et al. [2] introduced ionanofluids, the suspension of nanoparticles in ionic liquids as a new class of nanofluids. One of the first experimental investigations of ionanofluids was done by Altin et al. [3], who analysed the rheological properties of the suspensions of the nanoparticles in the ionic liquids. Following this, Wang et al. [4] and Altamash et al. [5] also experimentally analyzed the rheological properties of ionanofluids. They concluded that ionanofluids show non-Newtonian flow behavior. When it comes to the thermophysical properties of the ionanofluids, Nieto de Castro et al. [6] were among the first who conducted experimental investigations into the thermophysical properties of ionanofluids. They studied the thermal properties of imidazolium and pyrrolidinium and higher wall carbon nanoparticles, and concluded that nanoparticles cause improvement in the thermal conductivity and heat capacity of ionanofluids compared to the base fluids. Ionanofluids are mainly analyzed in 
respect to their thermophysical properties. The analyses were experimentally conducted by Fox et al. [7], Bridges et al. [8], Titan et al. [9-13] and Bhattacharjee et al. [14], while Minea et al. [15] gave a comparison of thermal conductivity for different ionanofluids. Fox et al. [7] experimentally investigated the influence of alumina nanoparticles on the thermophysical characteristics of ionanofluids, and showed that fibrously shaped A12O3 nanoparticles show a greater improvement in thermal conductivity. Bridges et al. [8] showed that the increased heat capacity of ionic fluids was improved with alumina particles without a detrimental effect on thermal stability. Titan et al. [9-13] showed that an increased heat transfer coefficient of forced convection and a deterioration in the natural heat transfer of a nanoionic fluid relative to an ionic fluid, as well as showing that there are significant improvements in the thermophysical characteristics of ionanofluids compared to the base ionic fluids. Besides the thermophysical properties, they also analyzed the rheological behavior of the ionanofluids and concluded that ionanofluids show non-Newtonian flow behavior.

As it can be seen from the literature overview, the experimental investigations of ionanofluids are rare in comparison to the published experimental investigations of the nanofluids. When it comes to the analyses of ionanofluids by using computational fluid dynamics, to the authors best knowledge there are only few studies available [16-23], whereas Said [24] analyzed the use of adaptive neuro fussy interface systems to predict the thermal conductivity and viscosity of ionanofluids. Computational fluid dynamic analyses of ionanofluids are mainly focused on the heat transfer performances.

Minea et al. [16] numerically analyzed heat transfer in a square enclosure filled with ionic liquid nanofluid. Although they stated that the thermophysical properties are temperature dependent, it can be concluded that they are only a function of initial temperature. Chereches et al. $[17,18]$ numerically analyzed heat transfer behavior of ionanofluids in laminar flow for different Reynolds numbers and one initial temperature for case without [17] and with [18] insulation over the pipe walls. Titan et al. [19] investigated the natural convection heat transfer of $\mathrm{Al}_{2} \mathrm{O}_{3}$ nanoparticle enhanced $\mathrm{N}$-butyl-N-methylpyrrolidinium bis $\{$ (trifluoromethyl)sulfonyl $\}$ imide $\left(\left[\mathrm{C}_{4} \mathrm{mpyrr}\right]\left[\mathrm{NTf}_{2}\right]\right)$ ionic liquid. The heat transfer performance of ionanofluids was also numerically analyzed by Prasad et al. [20] and Rupesh et al. [21]. Prasad et al. [20] analyzed the heat transfer in a 2-D flat plate, whereas Rupesh et al. [21] analyzed the heat transfer performance of ionanofluids around a circular cylinder. The most recent numerical investigations of the heat transfer behavior of particle suspension in ionic liquids were done by Shah et al. [22] and Bouchta et al. [23].

Although it has been shown that ionanofluids flow behavior corresponds to nonNewtonian flow, the assumption of Newtonian fluid was made in many studies [3-5,9-13]. In most numerical research a single-phase assumption was made, whereas the properties of ionanofluids are calculated as the properties of a mixture and a function of the weight percent of nanoparticles and base liquid. Furthermore, the studies all assumed that the properties are constant and related only to the initial and boundary conditions.

In this research, a numerical analysis of steady, laminar forced convection flow of $\mathrm{Al}_{2} \mathrm{O}_{3}$ nanoparticles in $\left(\left[\mathrm{C}_{4}\right.\right.$ mpyrr $\left.]\left[\mathrm{NTf}_{2}\right]\right)$ ionanofluids in a straight tube with constant heat flux on the tube wall for different Reynolds numbers and different values of initial and inlet temperature is presented. The heat transfer characteristic of the ionic liquid and ionanofluids for different weight percentages were analyzed and compared. The geometry was chosen due to its common application in solar collectors. The main contribution of this research is that this is, to the authors best knowledge, the first research on heat transfer characteristics of ionanofluids in which the thermophysical properties are temperature related and described in corresponding equations and implemented in such form. Moreover, the results are compared with results obtained for constant thermophysical properties for different initial temperature values. Although the term constant thermophysical properties is used, it must be emphasized that the thermophysical properties are a function of the initial/inlet temperature and therefore are constant for the same initial/inlet temperature. 


\section{Materials and Methods}

The mathematical model can be summarized in the following governing and constitutive equations:

Continuity equation

$$
\frac{\mathrm{d}}{\mathrm{d} t} \int_{V} \rho \mathrm{d} V+\int_{s} \rho v \cdot \mathrm{d} s=0
$$

where $\rho$ is density and $v$ is the velocity vector.

Momentum equation

$$
\frac{\mathrm{d}}{\mathrm{d} t} \int_{V} \rho v d V+\int_{S} \rho v v \cdot d s=\int_{S} \boldsymbol{T} \cdot d s+\int_{V} f_{b} d V
$$

where $T$ the Cauchy stress tensor and $f_{b}$ is the resultant body force.

Thermal energy equation

$$
\frac{\mathrm{d}}{\mathrm{d} t} \int_{V} \rho c_{v} T d V+\int_{s} \rho c_{p} T v \cdot d s=-\int_{s} \boldsymbol{q} \cdot d s+\int_{V}(T: \operatorname{grad} v) d V
$$

where $c_{p}$ is the specific heat, $T$ is the temperature and $q$ is the heat flux vector.

Stoke's law

$$
\mathbf{T}=2 \mu \dot{\boldsymbol{D}}-\frac{2}{3} \mu d i v v \boldsymbol{I}-P \boldsymbol{I}
$$

where

$$
\dot{D}=\frac{1}{2}\left[\operatorname{grad} v+(\operatorname{grad} v)^{\mathbf{T}}\right]
$$

is the rate of strain tensor, $\mu$ is the dynamic viscosity, $p$ is the pressure and $I$ is the unit tensor.

Fourier's law

$$
q=-k \operatorname{grad} T
$$

where $k$ is thermal conductivity.

Thermophysical properties of ionic liquid and ionanofluids.

Relationships for thermophysical properties (density, thermal conductivity, viscosity and specific heat) of ionanofluids $\left[\mathrm{C}_{4}\right.$ mpyrr $]\left[\mathrm{NTf}_{2}\right]$ with the $\mathrm{Al}_{2} \mathrm{O}_{3}$ nanoparticles used in this study are obtained by curve-fitting the experimental results from the literature [22] and are given in the Table 1. Additionally, relationships for certain properties, such as density, were already given by Titan [22] and are used as such.

Table 1. Equations used for predicting the thermophysical properties for different weight percent $w \mathrm{t} \%$.

\begin{tabular}{cccc}
\hline $\begin{array}{c}\text { Thermophysical } \\
\text { Property }\end{array}$ & Base Liquid & $\mathbf{0 . 5} \mathbf{w t} \%$ & $\mathbf{1 . 0} \mathbf{w t} \%$ \\
\hline Density, & $-7.77 \cdot 10^{-4} \mathrm{~T}+1.6129[22]$ & $-0.0008 T+1.6324$ & $-0.00087 T+1.665$ \\
{$\left[1000 \mathrm{~kg} \cdot \mathrm{m}^{-3}\right]$} & $8 \cdot 10^{23} T^{-10.15}$ & $3 \cdot 10^{22} T^{-9.544}$ & $2 \cdot 10^{27} T^{-11.46}$ \\
Viscosity, $[\mathrm{Pa} \cdot \mathrm{s}]$ & $-3 \cdot 10^{-6} T^{2}+0.0048 T+0.3941$ & $0.0016 T+1.7234$ & $-6 \cdot 10^{-6} T^{2}+0.0076 T+0.1891$ \\
Heat capacity, & & & $-8 \cdot 10^{28} T^{-11.93} T^{2}+0.01 T+0.2965$ \\
{$\left[\mathrm{~kJ} \cdot \mathrm{kg}^{-1} \cdot \mathrm{K}^{-1}\right]$} & $-6 \cdot 10^{-5} \mathrm{~T}+0.1398[22]$ & $-0.01 \ln T+0.1826$ & $-0.008 \ln T+0.1748$ \\
Thermal cond., & & & $-0.007 \ln T+0.1745$ \\
\hline $\left.\mathrm{W} \cdot \mathrm{m}^{-1} \cdot \mathrm{K}^{-1}\right]$ & & \\
\hline
\end{tabular}

The curve-fits are applied to the experimental values of the thermophysical properties obtained by Titan [22], and the results are presented in Figure 1. 


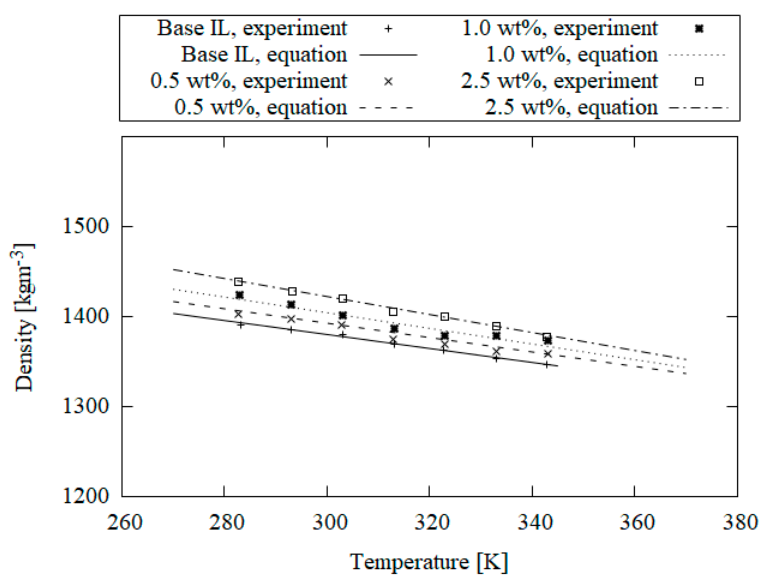

(a) Density

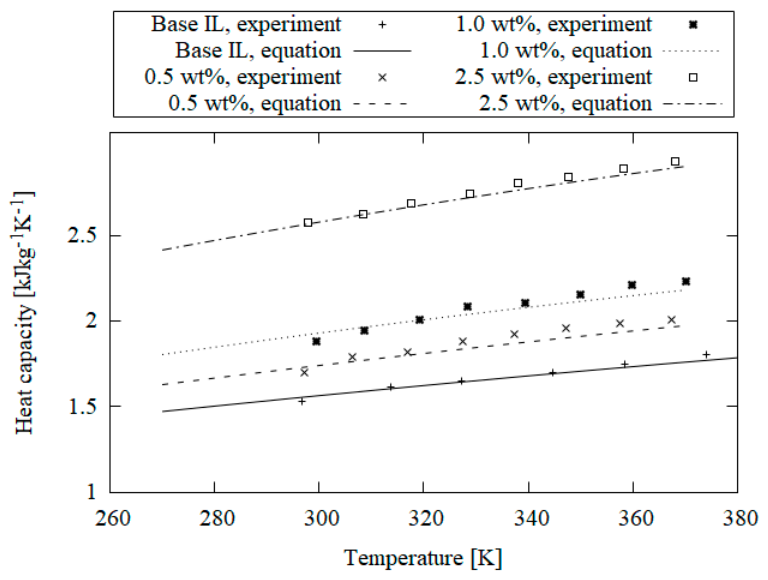

(c) Heat capacity

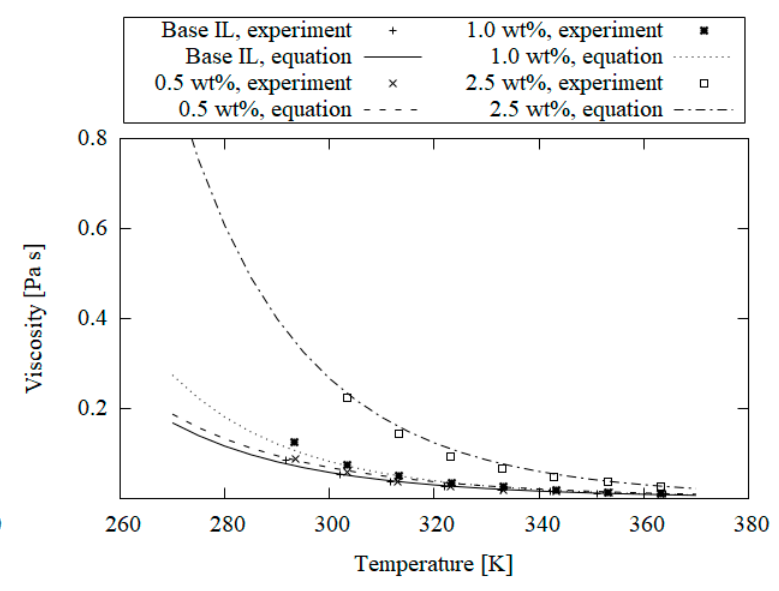

(b) Viscosity

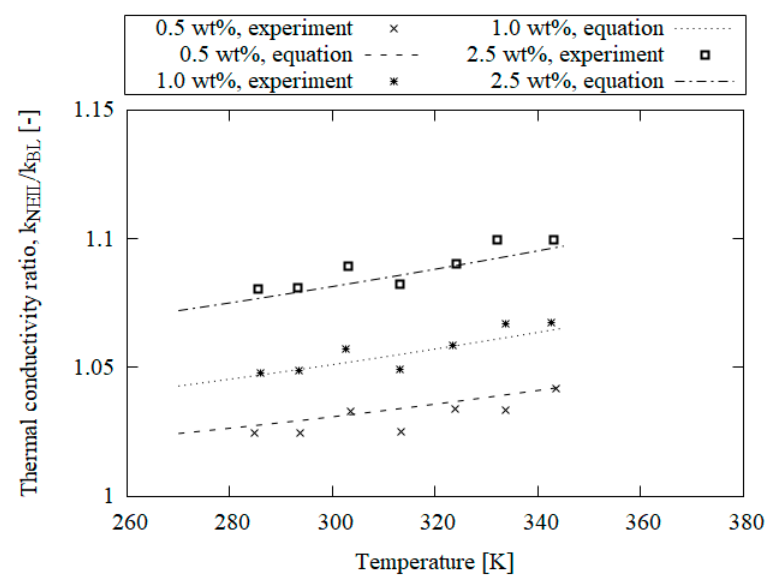

(d) Thermal conductivity ratio

Figure 1. Comparison of the predicted values for thermophysical properties using equations from Table 1 with measured data obtained by [22].

As it can be seen from Figure 1, the temperature variations of density (Figure 1a), viscosity (Figure 1b), heat capacity (Figure 1c) and ratio of thermal conductivity of base liquid and corresponding ionanofluids (Figure 1d) were compared with experimental results obtained by Titan [22]. The comparison was made for the base liquid as well as for ionanofluids with concentrations of $0.5,1.0$ and $2.5 \mathrm{wt} \%$ (weight percent). The square of correlation factor $\left(R^{2}\right)$ for density was above 0.95 , for viscosity above 0.99 , for heat capacity above 0.98 and for the ratio of thermal conductivity above 0.8 , regardless of weight percent.

The numerical method employed for modeling the flow and heat transfer of ionic liquid and ionanofluids was the finite volume method. The methodology closely follows the one presented in $[23,24]$.

\section{Results}

The steady-state flow of ionic liquid $\left[\mathrm{C}_{4}\right.$ mpyrr] $\left[\mathrm{NTf}_{2}\right]$ and ionanofluids with $\mathrm{Al}_{2} \mathrm{O}_{3}$ nanoparticles through the horizontal straight tube of $1.75 \mathrm{~m}$ length and $0.014 \mathrm{~m}$ diameter was analyzed with convective heat transfer included. The geometry of the problem can be seen from Figure 2. The case study was analyzed for initial temperatures $T_{i n 1}=293 \mathrm{~K}, T_{i n 2}=303 \mathrm{~K}$ and $T_{i n 3}=335 \mathrm{~K}$, for two Reynolds number values (100 and $512)$, and for three values of weight percentage $(0.5 \mathrm{wt} \%, 1.0 \mathrm{wt} \%$ and $2.5 \mathrm{wt} \%)$. Additionally, the heat transfer characteristics of pure ionic liquid was also analyzed. The wall 
heat flux was constant $q=13 \mathrm{~kW} \cdot \mathrm{m}^{-2}$. At the outlet, the pressure was set to $0 \mathrm{~Pa}$. For the purpose of set up, the inlet boundary conditions uniform velocity profile was used.

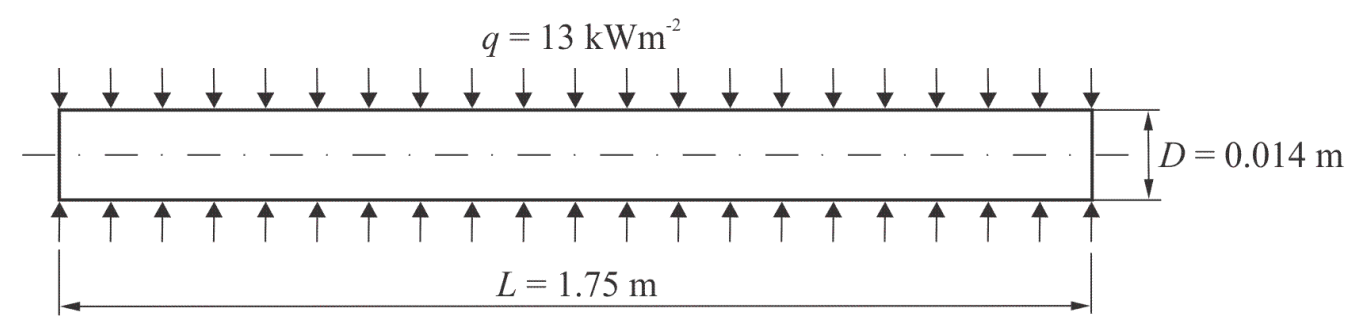

Figure 2. Geometry and boundary conditions.

The effects of natural convection were neglected. Due to computational efficiency, fluid flow was analyzed through a part of the tube in the shape of a longitudinal wedge with an angle of $5^{\circ}$ as it can be seen from Figure 3.

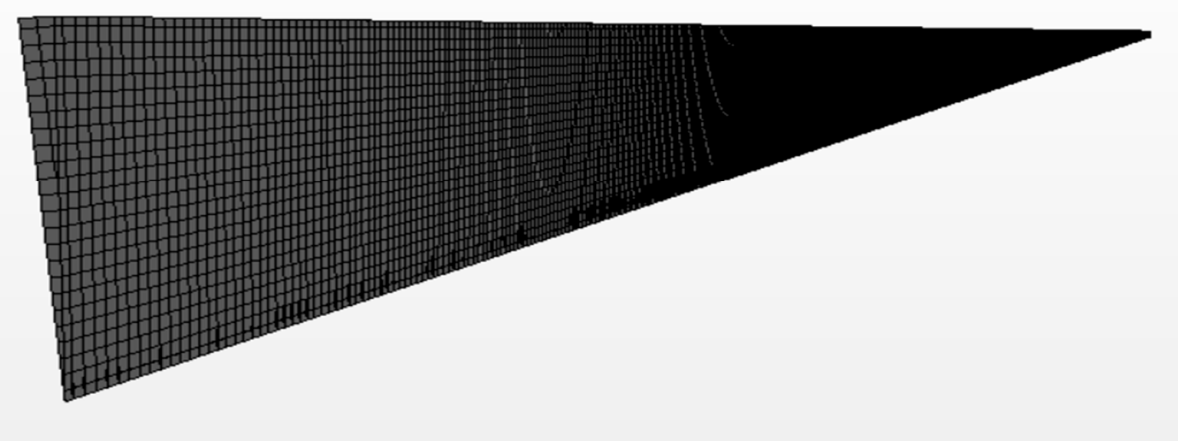

Figure 3. Geometry and mesh of longitudinal wedge with angle of $5^{\circ}$.

The heat transfer characteristics of the ionic liquid and corresponding ionanofluids were investigated by analyzing the heat transfer coefficient and Nusselt number. Additionally, the temperature profile for each case is presented.

The heat transfer coefficient and Nusselt number were calculated using the following equations:

$$
\begin{gathered}
h_{I L / N E I L}=\frac{q}{\left(T_{\text {wall }}-T_{\text {in }}\right)},\left[\mathrm{W} \cdot \mathrm{m}^{-2} \cdot \mathrm{K}^{-1}\right] \\
N u_{I L / N E I L}=h_{I L / N E I L} \frac{D}{k_{I L / N E I L}}[-]
\end{gathered}
$$

where

$q\left[\mathrm{~W} \cdot \mathrm{m}^{-2}\right]$ is heat flux through the shell of the tube given as the boundary condition

$T_{\text {wall }}[\mathrm{K}]$ is temperature of the tube shell

$T_{\text {in }}[\mathrm{K}]$ is initial (reference) temperature

$h_{\text {IL/NEIL }}\left[\mathrm{W} \cdot \mathrm{m}^{-2} \cdot \mathrm{K}^{-1}\right]$ is the heat transfer coefficient of the ionic liquid (IL) or ionanofluids (NEIL)

$D[\mathrm{~m}]$ is diameter of the tube ids (NEIL)

$k_{\text {IL/NEIL }}\left[\mathrm{W} \cdot \mathrm{m}^{-1} \cdot \mathrm{K}^{-1}\right]$ is the thermal conductivity of the ionic liquid (IL) or ionanoflu-

The validation of the presented model along with the grid refinement was done for the ionic liquid $\left[\mathrm{C}_{4}\right.$ mpyrr] $\left[\mathrm{NTf}_{2}\right]$ and the results were compared with results obtained by using the Shah's equation. The grid sensitivity study was performed for four different values of base cell sizes. The characteristics of the analyzed grids are given in Table 2. 
Table 2. Grid characteristics for grid sensitivity study.

\begin{tabular}{ccc}
\hline Grid & Characteristic Cell Size [mm] & Number of Cells \\
\hline 1 & 2.4 & 46,688 \\
2 & 1.2 & 198,356 \\
3 & 0.6 & $1,353,488$ \\
4 & 0.3 & $8,493,674$ \\
\hline
\end{tabular}

The results for each grid, and the results obtained by using Shah's equation, can be seen from Figure 4 . It can be seen from Figure 4 that as the grid is systematically refined, the results approach the results obtained from the Shah's equations.

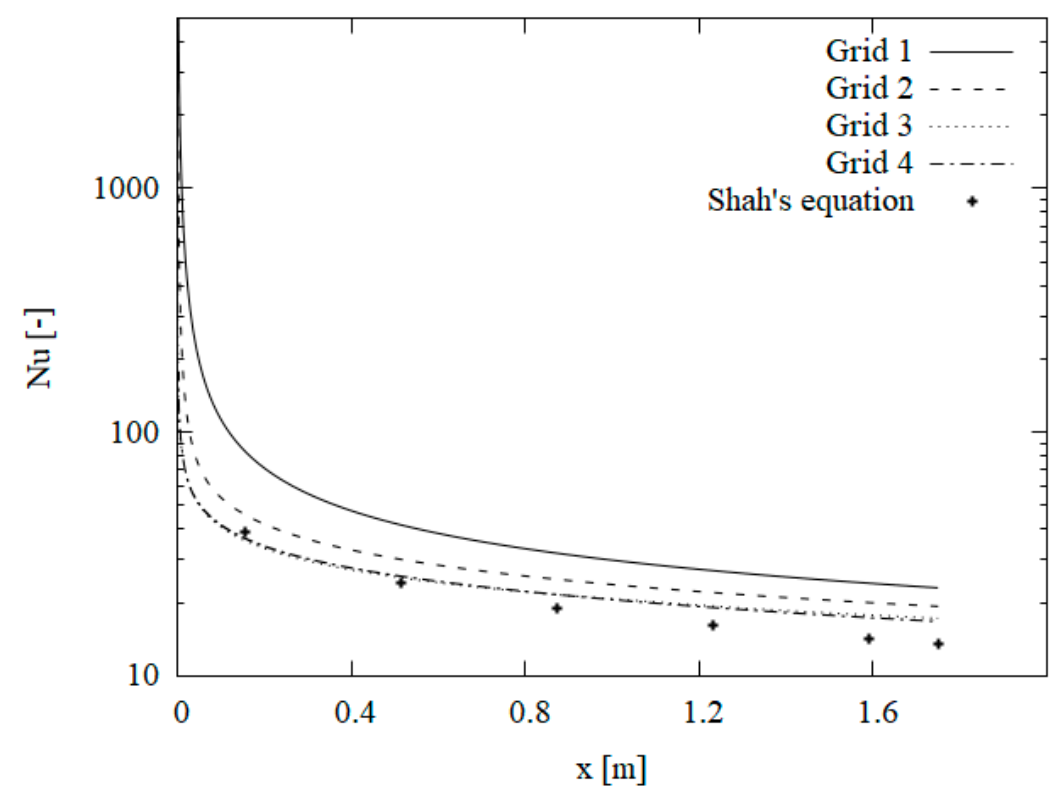

Figure 4. Grid sensitivity study and model validation.

Furthermore, one can conclude that for grid 3 (base cell size of $0.6 \mathrm{~mm}$ ), the obtained results are grid independent since for further refinement the results remain the same. Hence, the numerical study was performed for grid 3, with a base cell size of $0.6 \mathrm{~mm}$.

Over 40 numerical simulations were performed in order to compare temperature profiles and hence heat transfer characteristics (heat transfer coefficient and Nusselt number) for ionic liquid and ionanofluids with temperature-dependent thermophysical properties and with constant thermophysical properties. For better presentation of the findings, the results were compared in accordance with different perspectives, i.e., in accordance with the weight percent, Reynold numbers, initial temperatures, and/or in accordance with the temperature/dependency of thermophysical properties.

\section{Discussion}

Figure 5 presents the temperature distribution along the top wall, $T_{\text {wall }}$, at $R e=100$ and $R e=500$ and $0.5 \leq \mathrm{wt} \% \leq 2.5$ for fluids with constant thermophysical properties, whereas Figure 6 presents the temperature distribution along the top wall, $T_{\text {wall }}$, at $R e=100$ and $R e=500$ and $0.5 \leq \mathrm{wt} \% \leq 2.5$ for fluids with temperature-dependent thermophysical properties in accordance with Table 1. 


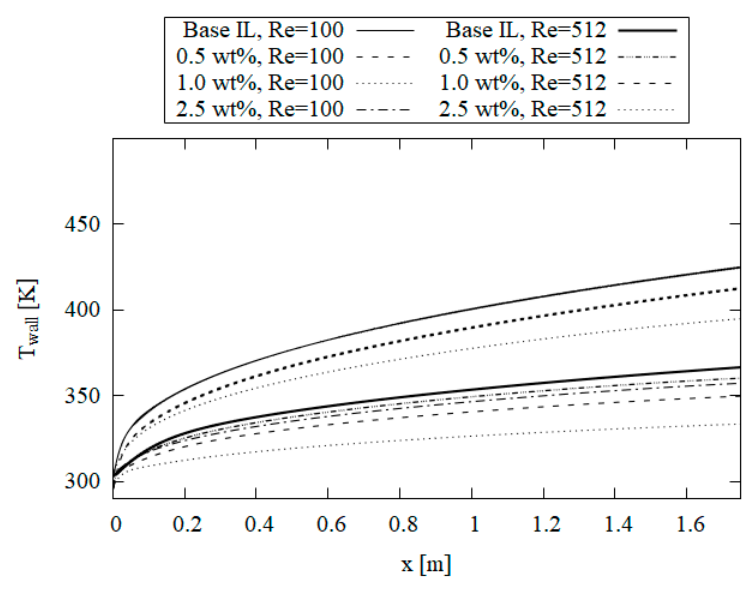

(a) $\mathrm{T}=293 \mathrm{~K}$

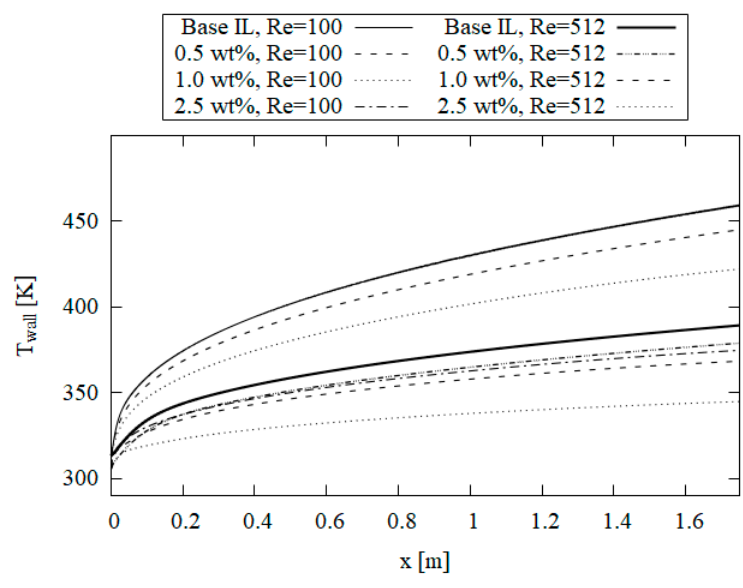

(b) $\mathrm{T}=303 \mathrm{~K}$

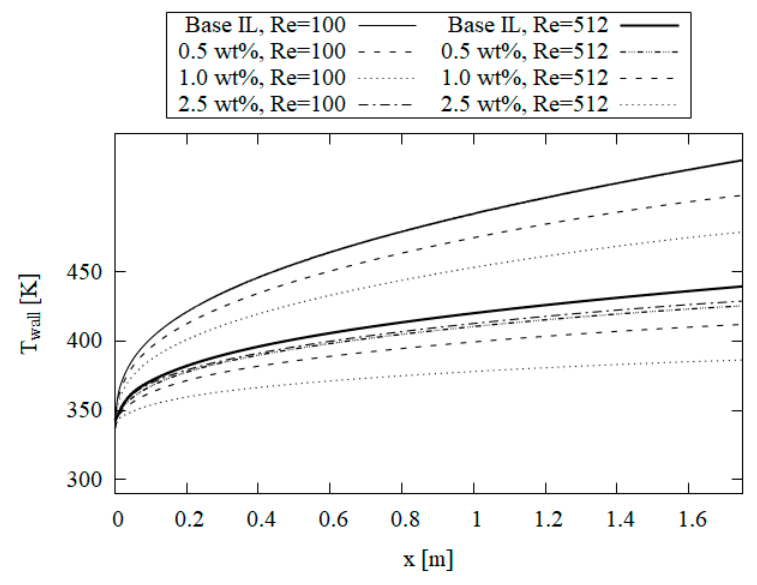

(c) $T=335 \mathrm{~K}$

Figure 5. Temperature profile for $R e=100$ and $R e=512$ for $0.5 \leq \mathrm{wt} \% \leq 2.5$ and constant thermophysical properties.

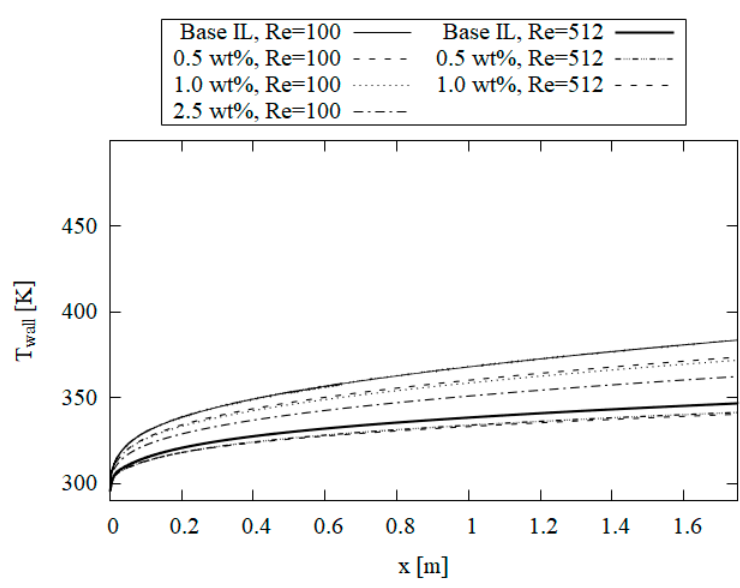

(a) $T=293 \mathrm{~K}$

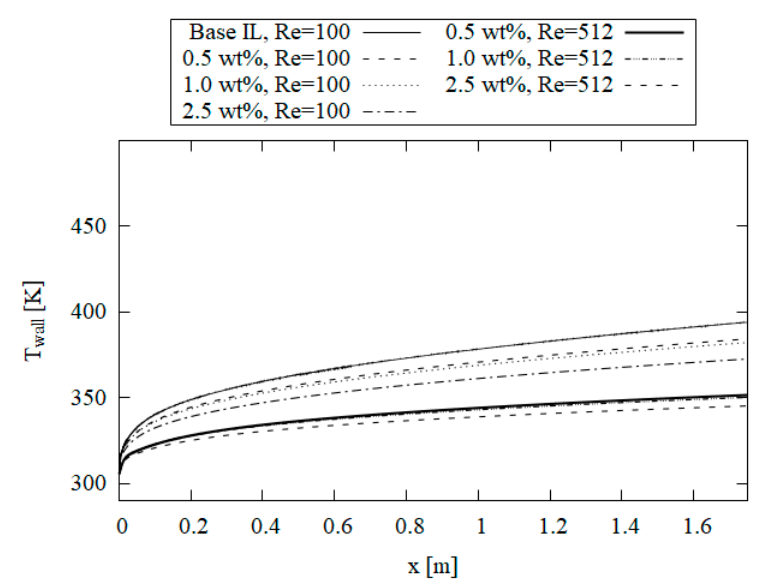

(b) $T=303 \mathrm{~K}$

Figure 6. Cont. 


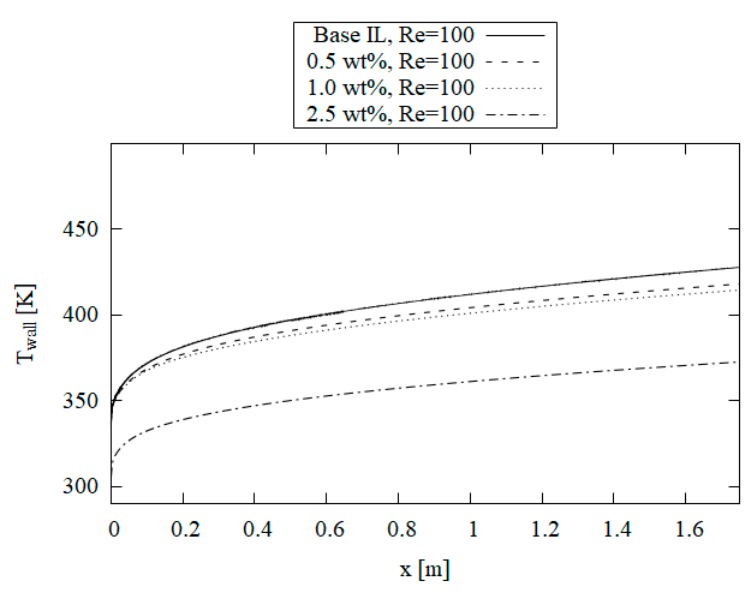

(c) $T=335 \mathrm{~K}$

Figure 6. Temperature profile for $R e=100$ and $R e=512$ for $0.5 \leq \mathrm{wt} \% \leq 2.5$ and temperature-dependent thermophysical properties.

It can be seen from the Figures 5 and 6 that the temperature at $x=0 \mathrm{~m}$ is same as the inlet temperature, and in the developing region (up to $x=0.4 \mathrm{~m}$ ) the immediate increase is noticeable. Following the gradual linear increase in the developed region due to the constant heat flux applied to the wall surface, the temperature at the upper wall reaches the maximum value at the outlet $(x=1.75 \mathrm{~m})$.

Furthermore, for both constant and temperature-dependent thermophysical properties, the increase in the weight percent of nanoparticles results in lower temperature profiles of the upper wall. One can conclude that the increase in the weight percent of nanoparticles results in more heat transfer from the wall to the fluid regardless of the temperature-dependency of the thermophysical properties. The same can be concluded for the influence of the Reynold's number; the increase in the Reynold's number results in an increase in heat transfer from the wall to the fluid for ionic liquid and ionanofluids for constant and temperature-dependent thermophysical properties.

To better understand the influence of the temperature-dependency of the thermophysical properties of the ionic liquid and ionanofluids on the temperature profile, Figure 7 presents the temperature distributions on the upper wall for $R e=100$, inlet temperatures $T=293 \mathrm{~K}, T=303 \mathrm{~K}$ and $T=335 \mathrm{~K}$ and $\mathrm{wt} \%$ of $0,0.5$ and 1.0 for both constant and temperature-dependent thermophysical properties.

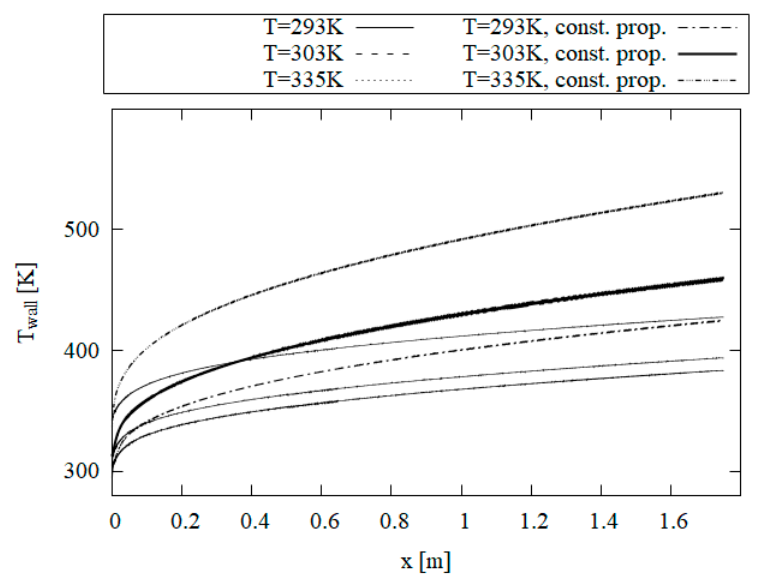

(a) Base IL

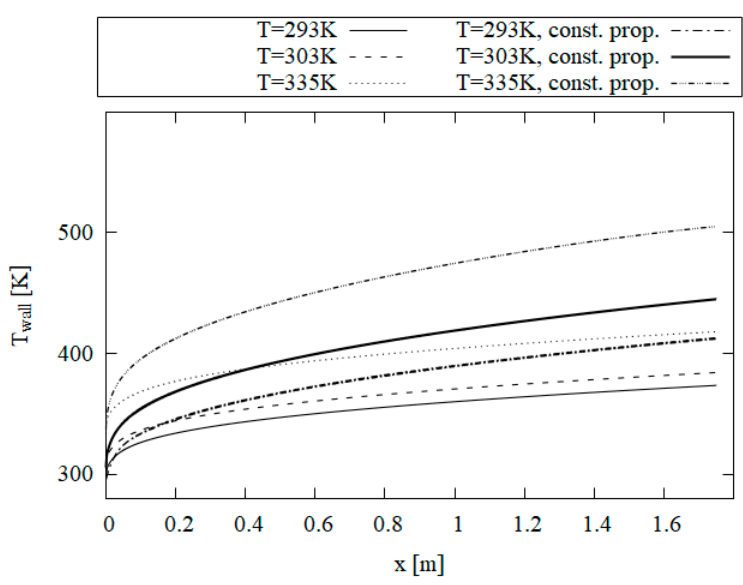

(b) $0.5 \mathrm{wt} \%$

Figure 7. Cont. 


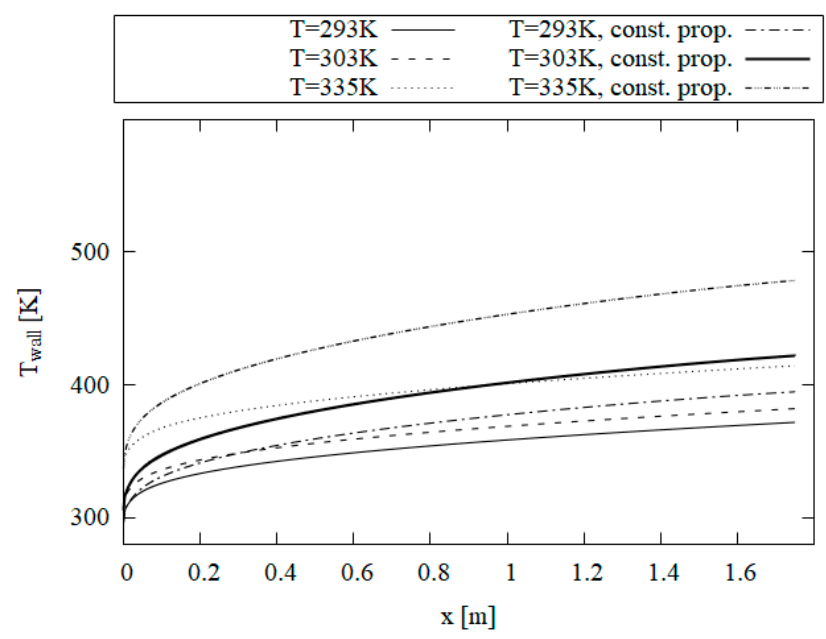

(c) $1.0 \mathrm{wt} \%$

Figure 7. Temperature profiles comparison for ionic liquid and ionanofluids with and without constant thermophysical properties for $R e=100$.

When analyzing the temperature profile on the upper wall for ionanofluids with and without constant properties for constant weight percent and Reynolds number, and with variable inlet temperatures, it can be concluded that the temperature profile is higher when the assumption of constant thermophysical properties is made, regardless of the weight percent or the inlet temperature. Therefore, it can be concluded that the temperaturedependent thermophysical properties of ionanofluids cause better heat transfer from the wall of the tube to the fluid.

Heat transfer performances of ionic liquid and ionanofluids for different weight percent were analyzed through the heat transfer coefficient (Equation (7)) and Nusselt number (Equation (8)). Figure 8 presents the heat transfer coefficient along the tube for ionic liquid, and ionanofluids of $0.5 \mathrm{wt} \%, 1.0 \mathrm{wt} \%$ and $2.5 \mathrm{wt} \%$, and for Reynolds numbers of 100 and 512 , for reference temperatures $T=293 \mathrm{~K}, T=303 \mathrm{~K}$ and $T=335 \mathrm{~K}$.

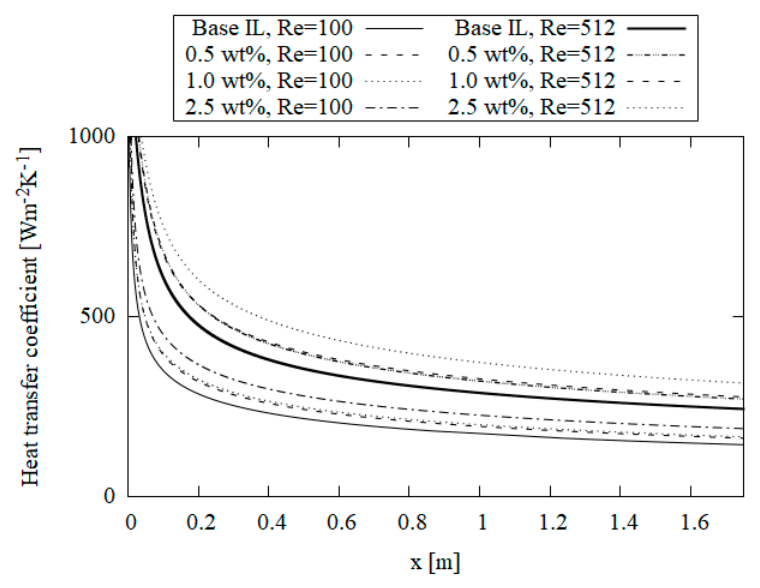

(a) $T=293 \mathrm{~K}$

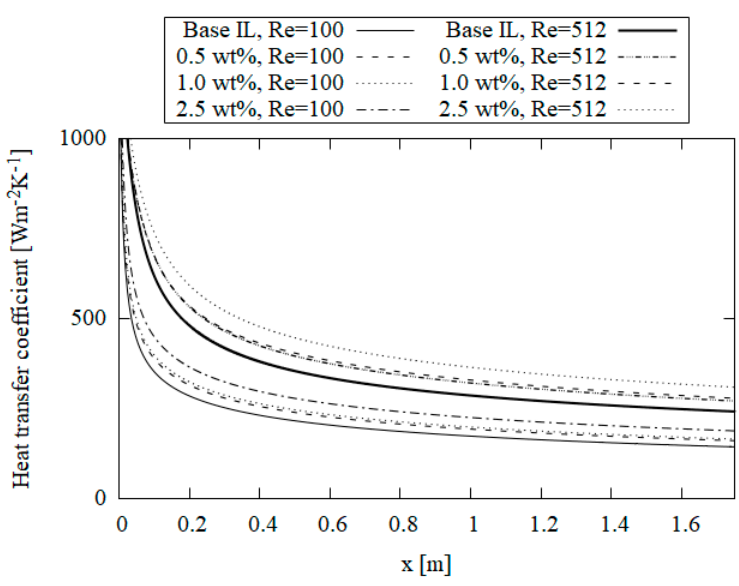

(b) $T=303 \mathrm{~K}$

Figure 8. Cont. 


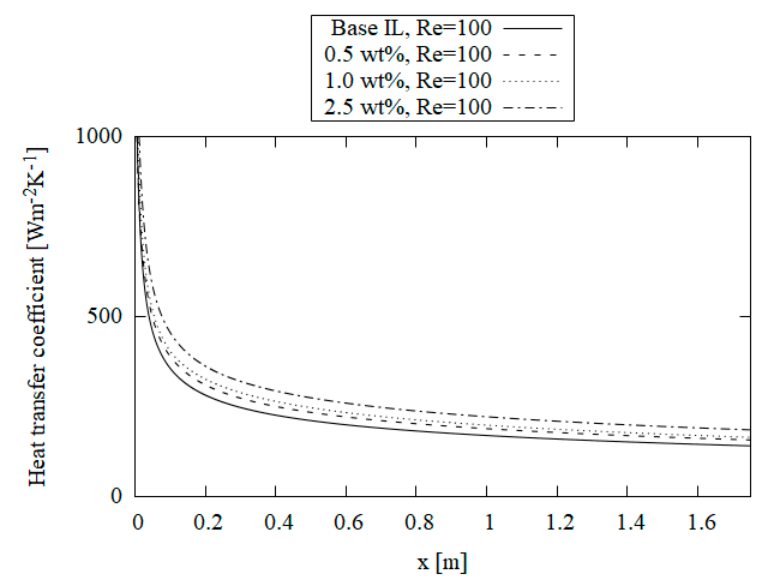

(c) $T=335 \mathrm{~K}$

Figure 8. Heat transfer coefficient for $0.5 \leq \mathrm{wt} \% \leq 2.5$ and $R e=100$ and $R e=512$.

It is shown in Figure 8 that the increase in the Reynolds number, as well as the increase in the nanoparticle weight percent, causes an increase in the heat transfer coefficient, meaning that the heat transfer is higher for higher values of $\mathrm{wt} \%$ and Re. The same conclusion can be made for each inlet temperature. Furthermore, it is noticeable that the heat transfer coefficient has the highest values at the inlet of the tube, leading to the exponential decrease in the developing region (up to $x=0.4 \mathrm{~m}$ ). Following this, the values of the heat transfer coefficient gradually decrease in a linear manner when progressing towards the outlet of the tube where the heat transfer coefficient has the minimum value.

Moreover, in this study, the influence of the assumption of the constant thermophysical properties on the heat transfer performances for ionic liquid and ionanofluids was analyzed. Therefore, Figure 9 presents the Nusselt number values along the tube for both ionanofluids with temperature-dependent thermophysical properties and for ionanofluids with constant thermophysical properties. Analysis was undertaken at a constant weight percentage, so that the influence of the assumption could be analyzed for different inlet temperatures and Reynolds numbers.

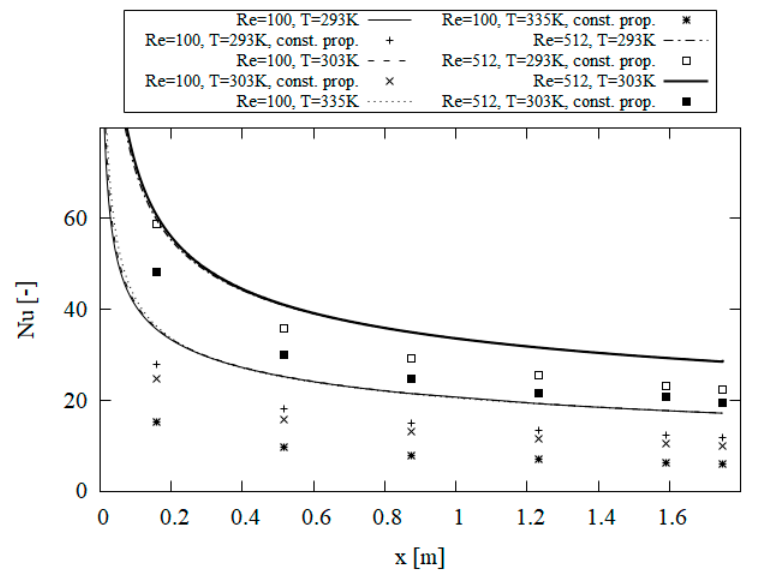

(a) Base IL

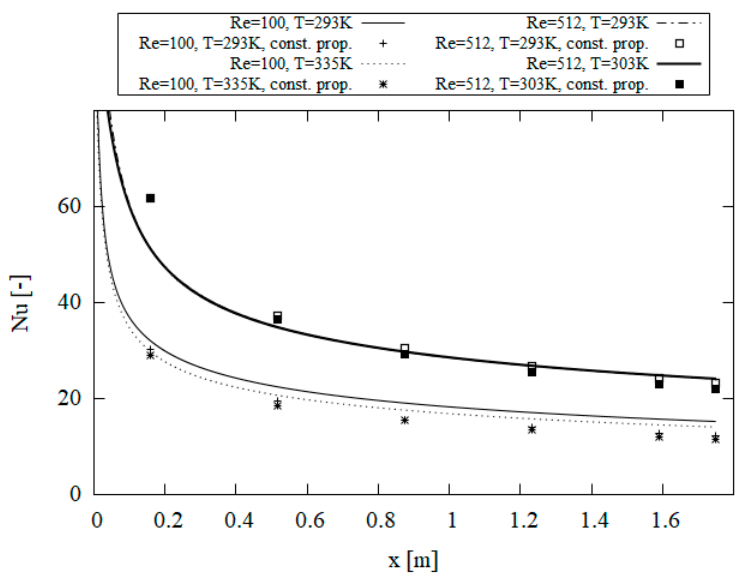

(b) $0.5 \mathrm{wt} \%$

Figure 9. Cont. 


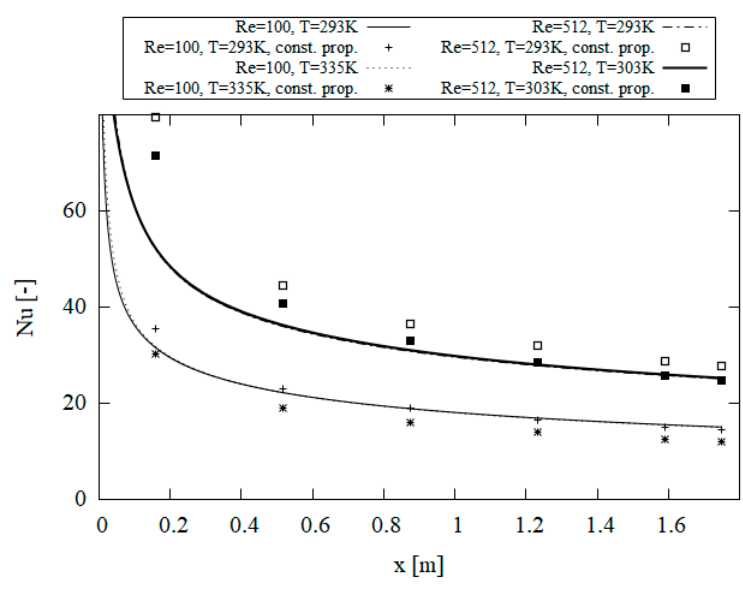

(c) $1.0 \mathrm{wt} \%$

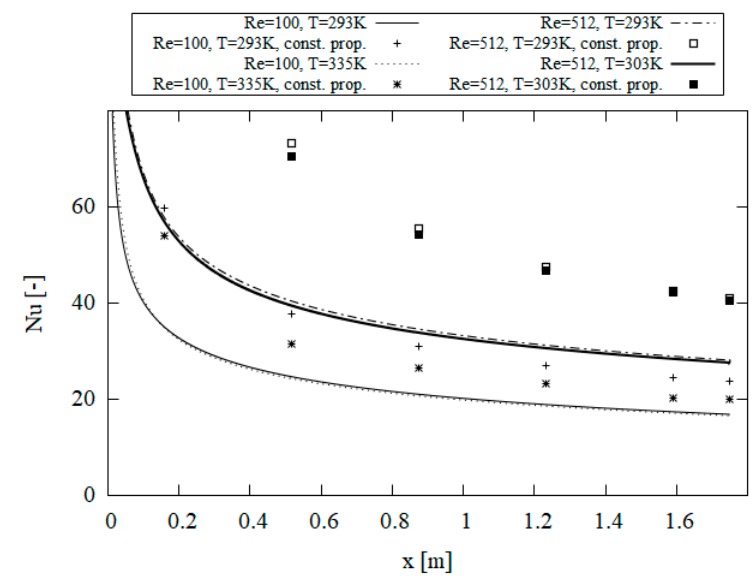

(d) $2.5 \mathrm{wt} \%$

Figure 9. Nusselt number for ionanofluids with and without constant thermal properties for different temperature values and different Reynold numbers.

When analyzing Figure 9, one can conclude that the assumption of the constant thermophysical properties of both ionic liquid and ionanofluids has a great influence on the Nusselt number. The influence is more significant as the weight percent increases. The greatest difference between the results for constant and variable thermophysical properties is for the weight percentage of $2.5 \%$, where significant divergence is noticeable for the Nusselt number, both for $R e=100$ and $R e=512$, as well as for each inlet temperature. When analyzing curves for the temperature-dependent thermophysical properties (Figure 1) it can be seen that, for $\mathrm{wt} \% 2.5$, the viscosity exponentially decreases, resulting in a significant difference in the viscosity values for different temperatures. The Nusselt number values for constant thermophysical properties for $R e=512$ and $T=293 \mathrm{~K}$ correspond to the Nusselt number values obtained by Chereches et al. [17].

For better understanding of the heat transfer performances of ionic liquids and ionanofluids, the heat transfer coefficient was analyzed and compared in accordance of weight percent for ionic liquid and ionanofluids, with and without constant properties for $R e=100$ (Figure 10) and $R e=512$ (Figure 11).

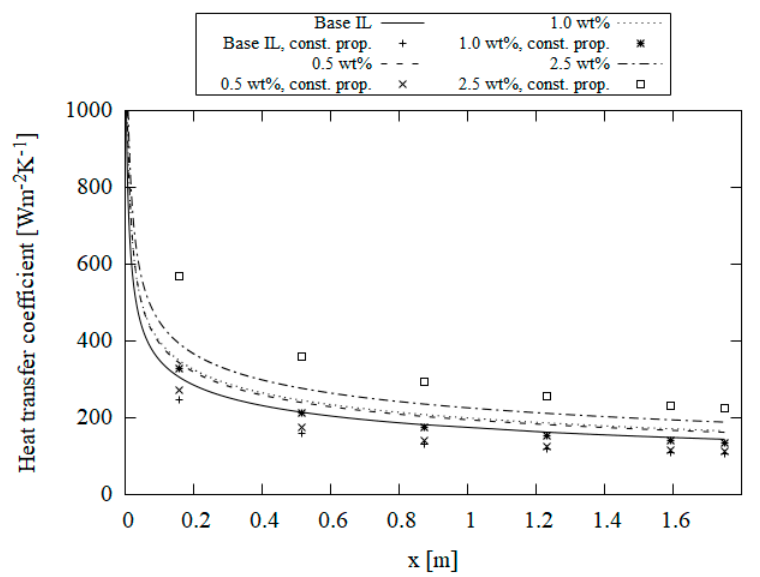

(a) $\mathrm{T}=293 \mathrm{~K}$

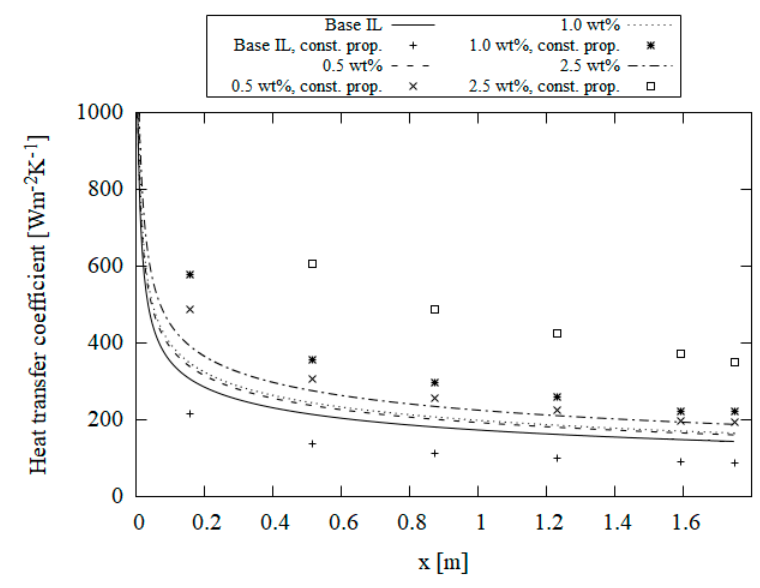

(b) $T=303 \mathrm{~K}$

Figure 10. Cont. 


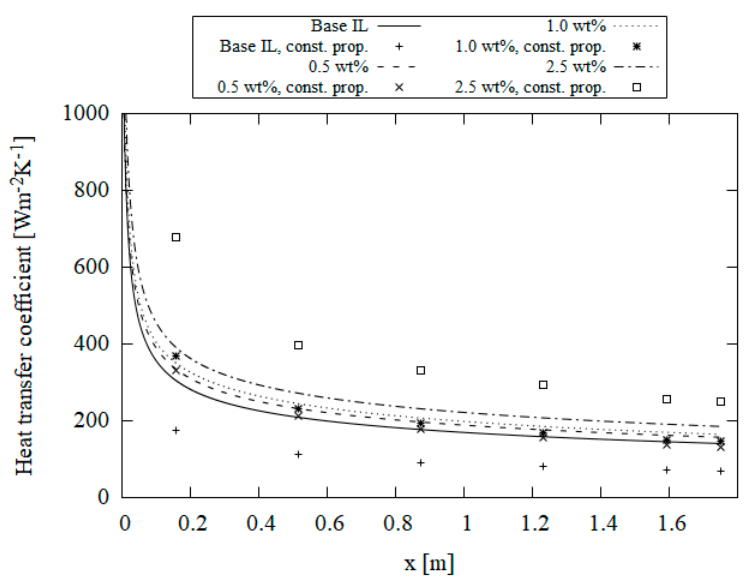

(c) $\mathrm{T}=335 \mathrm{~K}$

Figure 10. Heat transfer coefficient of ionic liquid and ionanofluids with and without constant thermal properties for $0.5 \leq \mathrm{wt} \% \leq 2.5$ and $R e=100$.

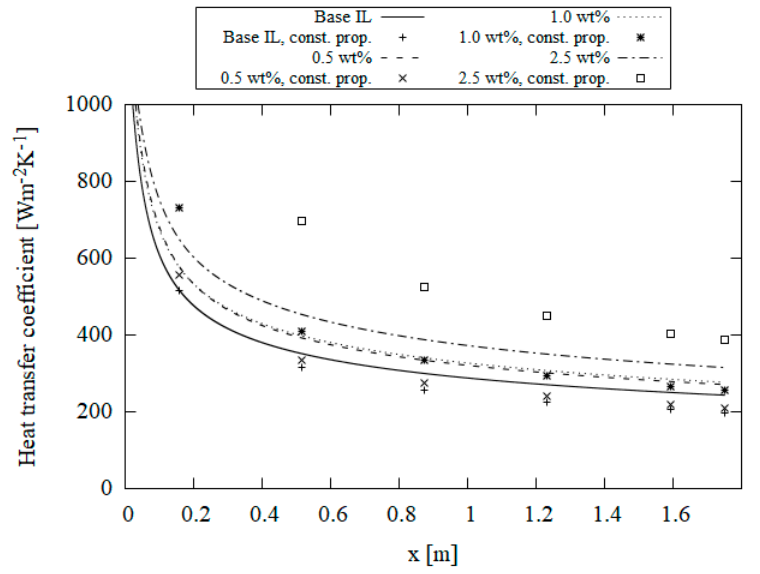

(a) $\mathrm{T}=293 \mathrm{~K}$

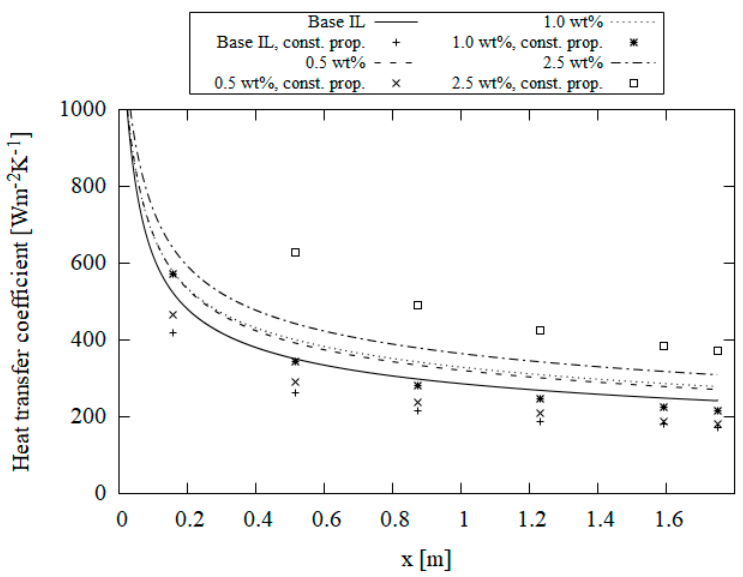

(b) $\mathrm{T}=303 \mathrm{~K}$

Figure 11. Heat transfer coefficient of ionic liquid and ionanofluids with and without constant thermal properties for $0.5 \leq \mathrm{wt} \% \leq 2.5$ and $R e=512$.

The heat transfer coefficient increases as the weight percent of ionanofluids increase, and it has the lowest value for ionic liquid for both $R e=100$ and $R e=512$, regardless of inlet temperature. Furthermore, it is noticeable from Figures 10 and 11 that the assumption of the constant thermophysical properties has the greatest influence on the heat transfer performances of the observed ionanofluids. The greatest influence is for those with a weight percent of $2.5 \%$. It can also be seen from Figures 10 and 11 that for ionic liquids and ionanofluids with constant thermophysical properties, the heat transfer coefficient is higher or lower (depending on the weight percent and inlet temperature), which can mislead a conclusion that the heat transfer performances are better or worse than they really are.

\section{Conclusions}

This paper presents a numerical investigation of the forced heat transfer of a ionic liquid $\left[\mathrm{C}_{4}\right.$ mpyrr] $\left[\mathrm{NTf}_{2}\right]$ and ionanofluids with $\mathrm{Al}_{2} \mathrm{O}_{3}$ nanoparticles through a straight tube. Geometric and physical models were defined that adequately describe the problems, as well as the numerical grid on which the simulations were performed in the STAR-CCM + 2019.2 software. Numerical research was undertaken with the following approximations: the effects of natural convection were neglected, and fluid flow through a part of the tube 
in the shape of a longitudinal wedge with angle of $5^{\circ}$ was analyzed. Thermophysical properties of the analyzed ionic liquid and ionanofluids were assumed to be a function of temperature. The adequate equations for each thermophysical property were gained via curve-fitting the experimental values with square of correlation factors above 0.95 for density relations, 0.99 for viscosity relations, 0.98 for heat capacity relations and for a ratio of thermal conductivity above 0.8 , regardless of weight percent. In order to obtain grid independent solutions, a grid sensitivity study was performed, and the model was validated with the results of Shah's equation. The presented analysis of the obtained results of the Nusselt number and the heat transfer coefficient of the ionic and nanoionic liquid shows the change in the considered parameters along the tube for different $\mathrm{w} \% \mathrm{~m}$ and different Reynolds numbers. During the analysis of the numerical results of the Nusselt numbers and the heat transfer coefficient of both the ionic and nanoionic liquid, a decrease in the Nusselt numbers and the heat transfer coefficient with a decrease of a $\mathrm{w} \%$ was found. Moreover, it is concluded that an increase in the Reynolds number results in an increase in both heat transfer coefficient and Nusselt number. The Nusselt number and the heat transfer coefficient of the ionic and nanoionic liquid decrease exponentially along the tube for any case under consideration. The results were compared against the results related to the ionic liquid and ionanofluids with constant thermophysical properties. It is concluded that the assumption that thermophysical properties are constant has a significant influence on the heat transfer performance parameters of both ionic liquid and ionanofluids, and therefore such assumptions should not be made in research.

Author Contributions: Conceptualization, A.H. and J.H.A.; methodology, A.H.; software, A.H. and J.H.A.; validation, A.H., S.B. and E.D.; formal analysis, J.H.A.; investigation, A.H. and J.H.A.; resources, J.H.A.; writing —original draft preparation, A.H.; writing—review and editing, S.B. and E.D.; visualization, J.H.A.; supervision, E.D.; project administration, A.H.; funding acquisition, A.H.. All authors have read and agreed to the published version of the manuscript.

Funding: This research was funded by Canton Sarajevo, Ministry for Science, Higher Education and Youth, grant number 27-02-11-4375-6/21. The APC was funded with that grant.

Institutional Review Board Statement: Not applicable.

Informed Consent Statement: Not applicable.

Data Availability Statement: Not applicable.

Conflicts of Interest: The authors declare no conflict of interest.

\section{References}

1. Choi, S.U.S. Enhancing thermal conductivity of fluids with nanoparticles. In Proceedings of the International Mechanical Engineering Congress and Exhibition, San Francisco, CA, USA, 12-17 November 1995.

2. Ribeiro, A.P.C.; Lourenco, M.J.V.; de Castro, C.A.N. Thermal conductivity of ionanofluids. In Proceedings of the 17 th Symposium on Thermophysical Properties, Boulder, CO, USA, 21-26 June 2009.

3. Altin, E.; Gradl, J.; Peukert, W. First studies on the rheological behavior of suspensions in ionic liquids. Chem. Eng. Technol. 2006, 29, 1347-1354. [CrossRef]

4. Wang, B.; Wang, X.; Lou, W.; Hao, J. Rheological and tribological properties of ionic liquid-based nanofluids containing functionalized multi-walled carbon nanotubes. J. Phys. Chem. C 2010, 114, 8749-8754. [CrossRef]

5. Altamash, T.; Atilhan, M.; Aliyan, A.; Ullah, R.; Nasser, M.; Aparicio, S. Rheological, thermodynamic, and gas solubility properties of phenylacetic acid-based deep eutectic solvents. Chem. Eng. Technol. 2017, 40, 778-790. [CrossRef]

6. De Castro, C.A.N.; Lourenco, M.J.V.; Ribeiro, A.P.C.; Langa, E.; Vieira, S.I.C. Thermal properties of ionic liquids and ionanofluids of imidaziolium and pyrrolidinium liquids. J. Chem. Eng. Data 2010, 55, 653-661. [CrossRef]

7. Fox, E.B.; Bridges, N.J.; Visser, A.E.; Amoroso, J.W. Thermophyiscal properties of nanoparticle-enhanced ionic liquids (NEILs) as advanced heat-transfer fluid. Energy Fuels 2013, 6, 3385-3393. [CrossRef]

8. Bridges, N.J.; Visser, A.E.; Fox, E.B. Potential of nanoparticle-enhanced ionic liquids (NEILs) as advanced heat-transfer fluid. Energy Fuels 2011, 10, 4862-4864. [CrossRef]

9. Titan, P.C.; Morshed, A.K.M.M.; Fox, E.B.; Khan, J.A. Effect of nanoparticle dispersion on thermophysical properties of ionic liquids for its potential application in solar collector. Procedia Eng. 2014, 90, 643-648. 
10. Titan, P.C. Investigation of Thermal Performance of Nanopatricle Enhanced Ionic Liquids (NEILs) for Solar Collector Applications. Ph.D. Thesis, Scholar Commons, University of South Carolina, Columbia, SC, USA, 2014.

11. Titan, P.C.; Morshed, A.K.M.M.; Fox, E.B.; Khan, J.A. Thermal performance of $\mathrm{Al}_{2} \mathrm{O}_{3}$ Nanoparticle Enhanced Ionic Liquids (NEILs) for Concentrated Solar Power (CSP) applications. Int. J. Heat Mass Transf. 2015, 85, 585-594.

12. Titan, P.C.; Morshed, A.K.M.M.; Khan, J.M.; Fox, E.B. Experimental investigation of natural convection heat transfer of Al2O3 Nanoparticle Enhanced Ionic Liquids (NEILs). Int. J. Heat Mass Transf. 2015, 83, 753-761.

13. Titan, P.C.; Morshed, A.K.M.M.; Fox, E.B.; Khan, J.A. Enhanced thermophysical properties of NEILs as heat transfer fluids for solar thermal applications. Appl. Therm. Eng. 2017, 110, 1-9.

14. Bhattacharjee, A.; Luis, A.; Santos, J.H.; Lopes-da-Silva, J.A.; Freire, M.G.; Carvalho, P.J.; Coutinho, J.A.P. Thermophysical properties of sulfonium-and ammonium-based ionic liquids. Fluid Phase Equlib. 2014, 381, 36-45. [CrossRef]

15. Minea, A.A.; Moldoveanu, M.G.; Dodun, O. Thermal conductivity enhancement by adding nanoparticles to ionic liquids. Sol. State Phenom. 2017, 261, 121-126. [CrossRef]

16. Minea, A.A.; El-Maghlany, W.M. Natural convection heat transfer utilizing ionic nanofluids with temperature-dependent thermophysical properties. Chem. Eng. Sci. 2017, 174, 13-24. [CrossRef]

17. Chereches, E.I.; Sharma, K.V.; Minea, A.A. A numerical approach in describing ionanofluids behavior in laminar and turbulent flow. Continuum Mech. Thermodyn. 2018, 30, 657-666. [CrossRef]

18. Chereches, E.I.; Chereches, M.; Alexandru, A.; Dima, A.; Minea, A.A. Nanoparticles in ionic liquids: Numerical evaluation of heat transfer behavior in laminar flow. Heat Transf. Eng. 2020, 42, 1625-1634. [CrossRef]

19. Titan, P.C.; Morshed, A.K.M.M.; Khan, J.A. Numerical investigation of natural convection of nanoparticle enhanced ionic liquids (NEILs) in enclosure heated from below. AIP Conf. Proc. 2016, 1754, 050019.

20. Prasad, S.S.; Selvakumar, R.D. Heat transfer performance of $\mathrm{Al}_{2} \mathrm{O}_{3}-\left(\left[\mathrm{C}_{4} \mathrm{mim}\right]\left[\mathrm{NTf}_{2}\right]\right)$ nano-suspension in a 2-D channel for application in a flat plate solar collector. IOP Conf. Ser. Mater. Sci. Eng. 2019, 577, 012006. [CrossRef]

21. Rupesh, S.; Selvakumar, R.D. Heat transfer performance of nano-suspension of $\mathrm{Al}_{2} \mathrm{O}_{3}$ in $\left(\left[\mathrm{C}_{4}\right.\right.$ mim $\left.]\left[\mathrm{NTf}_{2}\right]\right)$ ionic liquid around a circular cylinder. IOP Conf. Ser. Mater. Sci. Eng. 2019, 577, 012004. [CrossRef]

22. Shah, R.A.; Ullah, H.; Khan, M.S.; Khan, A. Parametric analysis of the heat transfer behavior of the nano-particle ionic-liquid flow between concentric cylinders. Adv. Mech. Eng. 2021, 13, 1-14. [CrossRef]

23. Bouchta, S.; Feddaoui, M.; Dayf, A. Numerical simulation of free convection in a partially heated three-dimensional enclosure filled with ionanofluid ([C $\left.\left.\mathrm{C}_{4} \mathrm{mim}\right]\left[\mathrm{NTf}_{2}\right]-\mathrm{Cu}\right)$. Math. Prob. Eng. 2021, 2021, 6696119. [CrossRef]

24. Sadi, M. Prediction of thermal conductivity and viscosity of ionic liquid-based nanofluids using adaptive neuro fuzzy interface system. Heat Transf. Eng. 2017, 38, 1561-1572. [CrossRef] 